\title{
Pathogens associated with impounded Pacific herring Clupea harengus pallasi, with emphasis on viral erythrocytic necrosis (VEN) and atypical Aeromonas salmonicida
}

\author{
G. S. Traxler, G. R. Bell \\ Department of Fisheries and Oceans, Biological Sciences Branch, Pacific Biological Station, Nanaimo, British Columbia, \\ Canada V9R 5K6
}

\begin{abstract}
Maturing Pacific herring (Clupea harengus pallasi Valenciennes) were captured and held in net pens at Departure Bay, British Columbia (Canada), to test the quality and timing of roe production. The health status of the impounded herring was regularly monitored during the 5 mo holding period. Viral erythrocytic necrosis (VEN) increased in the captive herring from an initial prevalence of $3 \%$ to $70 \%$ near the termination of holding. Bacteria isolated from kidneys of randomly sampled herring were tested for pathogenicity in juvenile herring. Significantly, 4 particularly virulent isolates were characterized as atypical Aeromonas salmonicida. Related experiments with herring in the laboratory indicated that they were capable of harbouring the important salmonid kidney disease pathogen Renibacterium salmoninarum for extended periods. In addition, 2 yr old herring (vaccinated parenterally with formalin-killed Vibrio anguillarum in adjuvant) failed to produce homologous serum agglutinins in $6 \mathrm{wk}$ although chinook salmon (Oncorhynchus tshawytscha) similarly vaccinated developed high agglutinin titres.
\end{abstract}

\section{INTRODUCTION}

Almost continuously since it began in 1877 the commercial harvesting of herring Clupea harengus pallasi Valenciennes has been an important component of Canada's Pacific coast fishing industry. With the development of the sac-roe (mature egg skeins) fishery in the early 1970s, 'herring have ranked second in landed value to the sum of all species of salmon and exceeded in value any single species' (Taylor 1985). Inseason management of the roe fishery has been described by Trumble \& Humphreys (1985), and it is evident that harvesting techniques could be damaging to spawning of survivors and to shallow spawning grounds. Pilot scale experiments on the off-shore (premature) capture, transportation, and impoundment of herring for maturation were conducted at the Pacific Biological Station for the purpose of reducing the possible detrimental effects of fishing gear and for diversifying the roe herring industry (Brett \& Solmie 1982).
One of the concerns in holding high densities of animals, especially following the stress of capture and transportation, is the possibility of high losses due to infectious disease. The status of infectious diseases of adult herring impounded to test the timing and quality of roe production was examined during the holding period and the results are reported herein. The protozoan and metazoan parasite fauna of herring from the Pacific coast of North America has been investigated by Arthur \& Arai (1980). Therefore, in the present investigation emphasis was placed on isolating and characterizing bacterial pathogens. In addition, the prevalence of viral erythrocytic necrosis (VEN), recently reported as associated with epizootics in feral herring in Alaska (Meyers et al. 1986), was monitored. The capability of herring to mount a specific immune response and the possibility that they could be a vector of the important salmonid pathogen Renbacterium salmoninarum were also investigated briefly. 


\section{MATERIAL AND METHODS}

Fish. Maturing herring were caught by seine, guided into a transportation vessel and released into net pens in Departure Bay, Nanaimo, British Columbia (B.C.), Canada. These herring were held at 2 densities, $14.8 \mathrm{~kg}$ $\mathrm{m}^{-3}$ (designated 'high density') and $11.6 \mathrm{~kg} \mathrm{~m}^{-3}$ ('medium density'), from January to June, 1982. A description of the methods of capture, transportation, and holding was given by Kreiberg, Brett \& Solmie (1982). Netpens P1 and P5 correspond to H1 and H5, respectively, in the report of Kreiberg et al. (1982).

Sampling: Every 2 wk, 30 active fish were netted randomly from each net pen and held alive in the laboratory until tissue samples were taken, within $1 \mathrm{~h}$ of capture. According to Ossiander \& Wedemeyer (1973) this sample size would enable, with $95 \%$ confidence, the detection of one or more infected herring in a population $>10^{5}$ with an assumed prevalence of detectable infection of 1 in 10 . Fish were killed with a blow to the head, the tail severed at the caudal peduncle, and blood collected immediately in heparinized capillary tubes for haematocrits and smears. This sampling procedure was used rather than selecting from the continuous, low percentage of moribund fish because we felt that a better measurement of the health status of fish that had survived the stress of capture and handling would be obtained. We would not merely be sampling those herring that had inevitably suffered physical damage.

Examination: Blood smears were stained with 'DiffQuik' (Dade Diagnostics Inc., Aguada, Puerto Rico) and examined microscopically for the presence of cytoplasmic inclusion bodies characteristic of VEN. Haematocrits were determined by centrifugation of caudal blood in heparinized capillary tubes for $3 \mathrm{~min}$ in a Clay-Adams microhaematocrit centrifuge. Bacteria were isolated by inoculating kidney tissue aseptically onto Difco Tryptic Soy Agar (TSA) and incubating at $15^{\circ} \mathrm{C}$. Kidney smears were prepared concurrently and Gram-stained for microscopic examination. Microscopic examination of blood and kidney smears consisted of scanning at least 50 fields at $1000 \times$ magnification but usefulness of kidney smears was limited because of the difficulty in detecting bacteria among the profuse melanin granules. Small pieces of gill from each fish were placed in Bouins' fixative for sectioning and staining.

Pathogenicity tests. The pathogenicity of 11 bacterial isolates from the kidneys of pen-held herring was tested using juvenile herring. Each of 2 groups of 20 herring was inoculated intraperitoneally, one group with $0.1 \mathrm{ml}$ of a high and another with a low dilution of a $24 \mathrm{~h}$ bacterial culture suspended in $0.1 \%$ peptone and $0.85 \%$ sodium chloride. The viable number of bacteria injected during each challenge was determined by the drop plate method of Miles \& Misra (1938). Both fish groups were fin-clipped to identify the challenge level received and then placed in the same tank. Controls (20 fish) were injected with $0.1 \mathrm{ml}$ of sterile peptone saline and placed in a separate tank. All fish were kept in $1 \times 1.7 \mathrm{~m}$ oval tanks (625 l) supplied with sea water at a flow rate of $20 \mathrm{l} \mathrm{min} \mathrm{m}^{-1}$. Kidney samples from all mortalities were Gram stained and cultured to confirm the cause of death in accordance with Koch's Postulates

Characterization of bacterial pathogens. Bacteria isolated from kidneys of inoculated fish were cultured on TSA, supplemented with $5 \%$ fetal bovine serum, $0.05 \%$ yeast extract and $1 \%$ sodium chloride, because there was sometimes difficulty in maintaining cultures on TSA alone. Biochemical tests were performed as described in the Manual of Microbiological Methods (1957). Oxidative or fermentative carbohydrate utilization was determined by the method of Hugh \& Liefson (1953). The test for sensitivity to the vibriostatic agent $0 / 129$ followed the procedure in Department of Fisheries and Oceans (1984).

Serological tests were performed on pathogenic isolates from herring to determine their antigenic characteristics. The indirect fluorescent antibody technique (IFAT) was employed using the procedure of Bullock \& Stuckey (1975). The immunodiffusion test followed the procedure described by Chen et al. (1974). The antisera used in the serological procedures were prepared by Grand Island Biological Company, against our reference strain of Aeromonas salmonicida (76-30). Other serological tests, employing 'A' protein monoclonal antibodies to confirm the identity of several of the isolates, were done by Dr T. Trust of the University of Victoria.

Immune response of herring. A separate experiment was conducted to measure the humoral immune response of $2 \mathrm{yr}$ old herring to vaccination with the immunogenic marine fish pathogen Vibrio anguillarum. Each of 3 groups of juvenile herring was inoculated intraperitoneally with $0.1 \mathrm{ml}$ of one of the following preparations: $0.85 \%$ saline, adjuvant, and $V$. anguillarum cells incorporated in adjuvant. The vaccine was prepared by emulsifying $1 \mathrm{ml}$ of formalinkilled cells in $3 \mathrm{ml}$ of Freund's complete adjuvant. The single injection administered to each fish contained 5 mg wet weight of bacteria. Chinook salmon Oncorhynchus tshawytscha were vaccinated identically to provide a positive control. It has been demonstrated that chinook salmon develop serum agglutinins following vaccination with Vibrio anguillarum (Antipa 1976). The background antibody levels from the same stock of unvaccinated herring were also measured.

Response to these treatments was determined by 


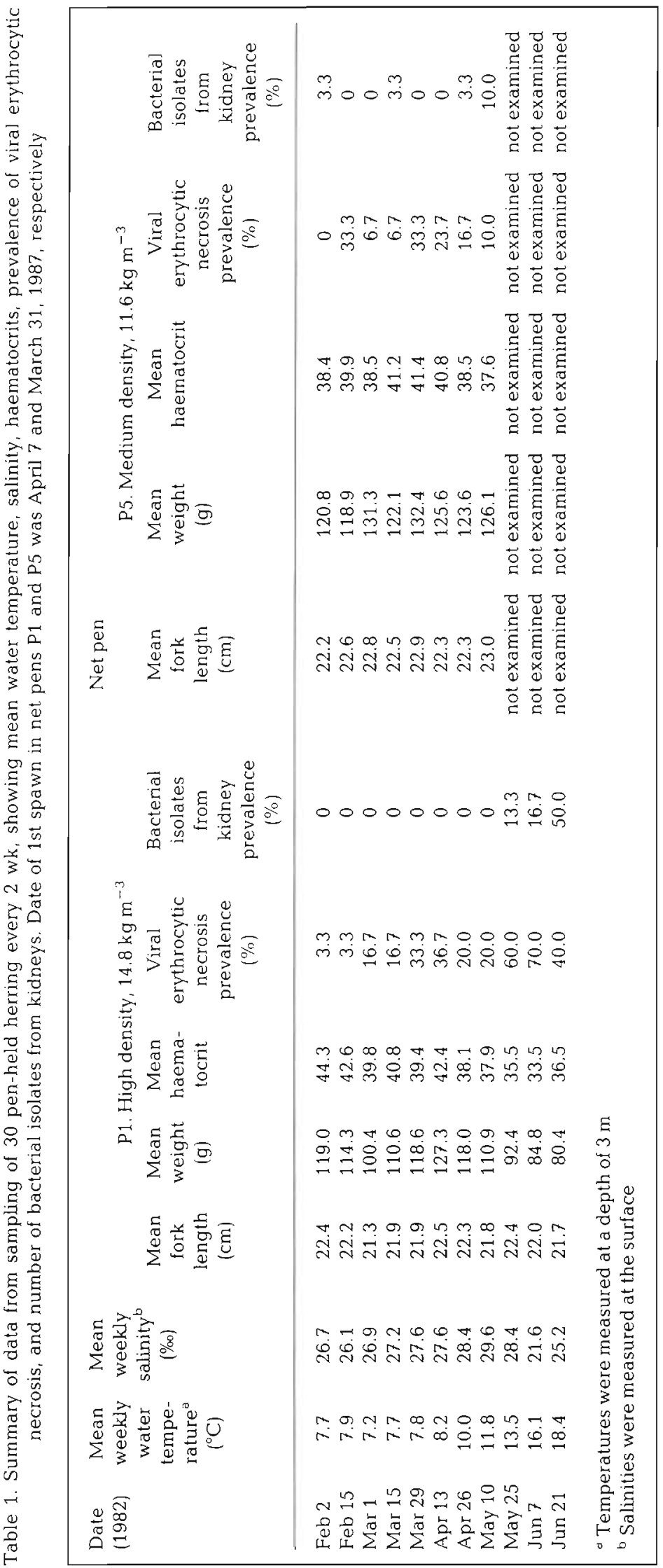


measuring the agglutinating titres of the plasma using standard microtitre procedures. Two-fold dilutions of serum in saline were mixed in ' $\mathrm{I}$ ' bottom trays with a heat-killed suspension of Vibrio anguillarum in saline adjusted to an absorbance of 2.5 at $420 \mathrm{~nm}$. Titres were recorded after $24 \mathrm{~h}$ incubation at $15^{\circ} \mathrm{C}$. Commercially prepared $V$. anguillarum antiserum was used as a secand positive control. Blood was collected from fish in heparinized capillary tubes, 6 wk after injection, by severing the caudal peduncle. Plasma was collected after centrifugation and stored at $-20^{\circ} \mathrm{C}$ until tested.

Water temperatures during incubation varied between 8.8 and $10^{\circ} \mathrm{C}$ for the herring and 9.5 to $12.0^{\circ} \mathrm{C}$ for the chinook salmon.

Susceptibility of herring to Renibacterium salmoninarum. In a preliminary but noteworthy expenment, 10 juvenile herring (mean wt $4.5 \mathrm{~g}$ ) were each inoculated intraperitoneally with $1.8 \times 10^{3} \mathrm{cfu}$ of a pathogenic culture of $R$. salmoninarum (our stock 384) and held in flowing sea water at $10^{\circ} \mathrm{C}$. Kidney tissue of all mortalities was examined by IFAT and culturing on KDM (Evelyn 1977) for the presence of the pathogen.

\section{RESULTS}

\section{Disease monitoring}

Herring survived well over the 5 mo holding period from January to May 1982, total mortality during the period of maturation and spawning being $10 \%$ in net pen P2 and $12.8 \%$ in net pen P5. The results of sampling herring once every $2 \mathrm{wk}$ from the net pens are shown in Table 1.

The prevalence of VEN in herring held in the high density net pen (P1) showed a marked increase during the holding period, rising from 3.3 to $70 \%$ near the termination while the mean haematocrit showed a declining trend. The lowest mean haematocrit occurred when the prevalence of VEN was highest. Herring held in the medium density net pen (P5) did not show any clear trend in either prevalence of VEN or in average haematocrits.

Thirty bacterial isolates were obtained from kidneys of herring with the majority being isolated near the end of the holding period. Most isolates were Gram-negative, pleomorphic rods often showing bipolar staining. Usually, only one representative isolate was retained for biochemical and pathogenicity testing. Only isolates that proved to be pathogenic were further characterized.

Histopathological examination of gills of 60 fish from pen $\mathrm{P} 1$ and 30 fish from pen P5, taken at 3 sampling dates near the end of the holding period, showed an overall $5 \%$ prevalence of the protozoan parasite Trichodina sp

\section{Pathogenicity tests}

Results of the pathogenicity tests for 11 bacterial isolates are summarized in Table 2. Mortalities recorded include only those fish from which the injected bacterial isolate was either observed in Gram stained kidney smears and/or re-isolated. Four of the bacterial isolates tested were highly virulent. When low bacterial concentrations of cultures $\mathrm{H} 3, \mathrm{H} 4, \mathrm{H} 5$, and $\mathrm{H} 8$ were inoculated intraperitoneally, half of the herring were killed in $16 \mathrm{~d}$ or less. The remaining isolates showed moderate to low virulence, indicated by the longer time to $50 \%$ mortality or, in some cases, a mortality of less than $50 \%$ over the observation period.

\section{Characterization of pathogens}

Some characteristics of the 4 highly virulent isolates are shown in Table 3. These isolates, identified as atypical Aeromonas salmonicida, all had similar morphological, and except for one test, identical biochemical characteristics. One of the above isolates differed from other atypical $A$. salmonicida isolated from marine species of fish (Evelyn 1971, Cornick et al. 1984, Dalsgaard \& Paulsen 1986) in its negative oxidase reaction. In addition to the characteristics listed in Table 3 , the isolates produced colonies that were difficult to disperse in saline and could be pushed intact along the surface of the agar with a loop or glass rod. The slow growth and fastidious nature of the isolates were characteristics similar to those of other atypical A. salmonicida as reported by Paterson et al. 1980. All 4 isolates proved antigenically similar to A. salmonicida according to the indirect fluorescent antibody and immunodiffusion tests, the latter of which produced precipitin lines with all 4 isolates that corresponded to those from a known $A$. salmonicida. No precipitin lines were observed when the isolates were tested with Vibrio anguillarum, Yersinia ruckeri, Renibacterium salmoninarum, or A hydrophila antisera. Further evidence of antigenic similarity to $A$. salmonicida was provided by Dr T. Trust with the use of monoclonal antibodies (pers. comm.) prepared against the ' $\mathrm{A}$ '-protein of $A$. salmonicida.

\section{Immune response}

Results of vaccination of herring and chinook salmon with Vibrio anguillarum are shown in Table 4. Agglutinin titres of plasma from herring in the 3 control groups were extremely low, none of the fish having detectable antibody levels to $V$. anguillarum. Similarly, the chinook salmon control groups had low plasma antibody levels. 
When the complete vaccine was administered to herring about half the fish showed a weak response, while the same vaccine produced high homologous agglutinin titres in chinook salmon.

\section{Susceptibility to Renibacterium salmoninarum}

All inoculated herring had died by $74 \mathrm{~d}$ post injection (p.i.), 6 with microscopically and culturally confirmed $R$. salmoninarum infection. These 6 mortalities occurred at 33 ( 2 fish), 47,61,68, and 74 d p.i. Saline-injected controls also died over the $125 \mathrm{~d}$ holding period, but with no evidence of $R$. salmoninarum infection.

\section{DISCUSSION}

The signs of EN virus infection observed in blood smears of the pen-held herring were similar to those described by Evelyn \& Traxler (1978) for VEN infections in Pacific salmon. Affected erythrocytes contained a single, round, pink cytoplasmic inclusion body which is pathognomonic for EN virus infection. Severity of the

Table 2. Results of pathogenicity testing of 2 concentrations of bacteria isolated from pen-held herring when injected into each of 2 groups of 20 juvenile herring. When $50 \%$ mortality did not occur in the time allotted for the challenge, number of days and final mortality are shown

\begin{tabular}{|c|c|c|c|c|c|c|c|}
\hline $\begin{array}{l}\text { Bacterial } \\
\text { isolate }\end{array}$ & $\begin{array}{l}\text { Net-pen } \\
\text { bacteria } \\
\text { isolated } \\
\text { from }\end{array}$ & $\begin{array}{l}\text { Number of } \\
\text { bacteria } \\
\text { injected }\end{array}$ & $\begin{array}{c}\text { Number of } \\
\text { days to } 50 \% \\
\text { mortality }\end{array}$ & $\begin{array}{c}\text { Mean } \\
\text { weight } \\
\text { (g) }\end{array}$ & $\begin{array}{l}\text { Mean } \\
\text { length } \\
\text { (cm) }\end{array}$ & $\begin{array}{l}\text { Temperature } \\
\text { range during } \\
\text { challenge }\left({ }^{\circ} \mathrm{C}\right)\end{array}$ & Virulence \\
\hline $\mathrm{H} 1$ & P5 & $\begin{array}{l}1.0 \times 10^{6} \\
1.0 \times 10^{4} \\
\text { Control }\end{array}$ & $\begin{array}{l}\text { No mortalities } \\
\text { caused by } \\
\text { injected bacteria }\end{array}$ & $\begin{array}{l}7.0 \\
6.1 \\
6.3\end{array}$ & $\begin{array}{l}10.5 \\
10.2 \\
10.2\end{array}$ & $11.3-13.0$ & Non-pathogenic \\
\hline $\mathrm{H} 2$ & P5 & $\begin{array}{l}6.7 \times 10^{3} \\
6.7 \times 10^{1} \\
\text { Control }\end{array}$ & $\begin{array}{l}18 \\
20\end{array}$ & $\begin{array}{l}6.6 \\
6.4 \\
6.3\end{array}$ & $\begin{array}{r}10.2 \\
9.9 \\
10.3\end{array}$ & $11.3-13.0$ & Moderate \\
\hline $\mathrm{H} 3$ & P5 & $\begin{array}{l}1.5 \times 10^{4} \\
1.5 \times 10^{2} \\
\text { Control }\end{array}$ & $\begin{array}{l}11 \\
16\end{array}$ & $\begin{array}{l}4.7 \\
4.6 \\
5.0\end{array}$ & $\begin{array}{l}8.4 \\
8.7 \\
8.6\end{array}$ & $9.7-10.6$ & High \\
\hline $\mathrm{H} 4$ & P5 & $\begin{array}{l}6.6 \times 10^{5} \\
6.6 \times 10^{3} \\
\text { Control }\end{array}$ & $\begin{array}{l}5 \\
8 \\
31(10 \%)^{4}\end{array}$ & $\begin{array}{l}3.8 \\
4.0 \\
3.8\end{array}$ & $\begin{array}{l}8.1 \\
8.1 \\
8.6\end{array}$ & $12.0-12.3$ & High \\
\hline $\mathrm{H} 5$ & P5 & $\begin{array}{l}4.4 \times 10^{3} \\
4.4 \times 10^{1} \\
\text { Control }\end{array}$ & $\begin{array}{l}11 \\
15\end{array}$ & $\begin{array}{l}4.4 \\
5.1 \\
5.4\end{array}$ & $\begin{array}{l}8.4 \\
8.8 \\
9.1\end{array}$ & $9.7-10.6$ & High \\
\hline $\mathrm{H} 6$ & P1 & $\begin{array}{l}4.4 \times 10^{7} \\
4.4 \times 10^{5} \\
\text { Control }\end{array}$ & $\begin{array}{l}35 \\
42(40 \%)\end{array}$ & $\begin{array}{l}5.8 \\
5.5 \\
5.0\end{array}$ & $\begin{array}{l}9.1 \\
9.4 \\
8.9\end{array}$ & $10.0-11.7$ & Low \\
\hline $\mathrm{H7}$ & P1 & $\begin{array}{l}3.0 \times 10^{7} \\
3.0 \times 10^{5} \\
\text { Control }\end{array}$ & $\begin{array}{l}15 \\
25 \\
31(10 \%)^{a}\end{array}$ & $\begin{array}{l}4.3 \\
2.9 \\
3.8\end{array}$ & $\begin{array}{l}8.9 \\
7.9 \\
8.6\end{array}$ & $12.0-14.5$ & Moderate \\
\hline $\mathrm{H} 8$ & P1 & $\begin{array}{l}1.4 \times 10^{3} \\
1.4 \times 10^{1} \\
\text { Control }\end{array}$ & $\begin{array}{r}8 \\
13\end{array}$ & $\begin{array}{l}6.0 \\
5.4 \\
6.8\end{array}$ & $\begin{array}{l}9.1 \\
9.1 \\
9.6\end{array}$ & $12.0-12.3$ & High \\
\hline $\mathrm{H} 9$ & P1 & $\begin{array}{c}1.8 \times 10^{4} \\
1.8 \times 10^{2} \\
\text { Control }\end{array}$ & $\begin{array}{l}37(20 \%) \\
37(15 \%)\end{array}$ & $\begin{array}{l}6.4 \\
6.4 \\
7.3\end{array}$ & $\begin{array}{l}10.1 \\
10.2 \\
10.4\end{array}$ & $11.3-12.2$ & Low \\
\hline $\mathrm{H} 10$ & P1 & $\begin{array}{c}4.5 \times 10^{3} \\
4.5 \times 10^{1} \\
\text { Control }\end{array}$ & $\begin{array}{l}17 \\
20(40 \%)\end{array}$ & $\begin{array}{l}6.1 \\
7.2 \\
6.8\end{array}$ & $\begin{array}{r}9.6 \\
10.2 \\
9.9\end{array}$ & $11.3-13.7$ & Moderate \\
\hline H11 & P1 & $\begin{array}{l}4.6 \times 10^{7} \\
4.6 \times 10^{5} \\
\text { Control }\end{array}$ & $\begin{array}{l}27 \\
35\end{array}$ & $\begin{array}{l}5.7 \\
5.8 \\
4.9\end{array}$ & $\begin{array}{l}9.6 \\
9.4 \\
8.9\end{array}$ & $10.4-11.7$ & Low \\
\hline
\end{tabular}


Table 3. Characteristics of the 4 virulent bacterial isolates (H.3. H4, H5, and H8) from herring

\begin{tabular}{|c|c|}
\hline Cell morphology & Gram-negative rods exhibiting bipolar staining, $1 \times 2$ !n \\
\hline $\begin{array}{l}\text { Colony characteristics } \\
\text { on serum supplemented TSA }\end{array}$ & $\begin{array}{l}\text { Translucent, punctiform, raised, entire } \\
\text { margins, no brown diffusing pigment }\end{array}$ \\
\hline Motility & Negative \\
\hline Catalase & Positive \\
\hline Oxidase & $3 / 4$ positive; $1 / 4$ negative \\
\hline Indole & Negative \\
\hline Temperature range & Grows at $15^{\circ} \mathrm{C}$, colonies in 5 to $7 \mathrm{~d}$, no growth at $37^{\circ} \mathrm{C}$ \\
\hline Glucose utilization & Fermentative - gas \\
\hline Serologic characteristics & $\begin{array}{l}\text { Indirect fluorescent antibody terhnique (IFAT), positive for Aeromonas salmonicida; } \\
\text { immunodiffusion test, positive for A. salmonicida }\end{array}$ \\
\hline $\begin{array}{l}\text { Growth in the presence } \\
\text { of vibriostatic agent } 0 / 129\end{array}$ & Negative \\
\hline
\end{tabular}

Table 4. Plasma agglutinin titres of herring and chinook salmon vaccinated with Vibrio anguillarum

\begin{tabular}{|c|c|c|c|c|c|c|c|}
\hline & \multicolumn{4}{|c|}{ Herring ${ }^{d}$} & \multicolumn{3}{|c|}{ Chinook salmon ${ }^{b}$} \\
\hline & $\begin{array}{l}\text { Initial } \\
\text { stock }\end{array}$ & $\begin{array}{l}\text { Saline } \\
\text { control }\end{array}$ & $\begin{array}{l}\text { Adjuvant } \\
\text { control }\end{array}$ & $\begin{array}{c}\text { Complete } \\
\text { vaccine }\end{array}$ & $\begin{array}{l}\text { Saline } \\
\text { control }\end{array}$ & $\begin{array}{l}\text { Adjuvant } \\
\text { control }\end{array}$ & $\begin{array}{c}\text { Complete } \\
\text { vaccine }\end{array}$ \\
\hline Number tested & 30 & 28 & 28 & 32 & 16 & 29 & 26 \\
\hline Mean haematocrit & 43 & 40 & 38 & 39 & 44 & 43 & 43 \\
\hline Agglutinin titer & \multicolumn{7}{|c|}{ Number of plasma samples with agglutinins at dilution shown } \\
\hline$<1 / 2$ & 30 & 28 & 28 & 16 & 14 & 6 & \\
\hline $1 / 2$ & & & & 13 & 2 & 22 & \\
\hline $1 / 4$ & & & & 3 & & 1 & \\
\hline \multicolumn{8}{|l|}{$1 / 8$} \\
\hline \multicolumn{8}{|l|}{$1 / 16$} \\
\hline \multicolumn{8}{|l|}{$1 / 32$} \\
\hline $1 / 64$ & & & & & & & 1 \\
\hline $1 / 128$ & & & & & & & 5 \\
\hline $1 / 256$ & & & & & & & 8 \\
\hline $1 / 512$ & & & & & & & 7 \\
\hline $1 / 1024$ & & & & & & & 3 \\
\hline $1 / 2048$ & & & & & & & 2 \\
\hline \multicolumn{8}{|c|}{ Means: fork length $18.4 \mathrm{~cm}$; wt $57.8 \mathrm{~g}$} \\
\hline
\end{tabular}

infections increased the longer the herring were held, as was evidenced by the increased number of erythrocytes observed with inclusions and the corresponding lower haematocrits in the infected fish. Source of the virus was not apparent from this study. However, studies by Meyers et al. (1986) showed that wild stocks of herring in Alaska are naturally infected with EN virus. It is likely, therefore, that the pen-held herring were carriers of the virus and the stress of capture, transport, and holding elicited the outbreak of VEN.

It has been shown that the EN virus carried by Pacific herring is capable of infecting chum (Oncorhynchus keta) and pink (O. gorbuscha) salmon by intraperitoneal injection (Evelyn \& Traxler 1978, MacMillan \& Mulcahy 1979). Waterborne transmission of EN virus has been demonstrated by MacMillan \& Mulcahy (1979). Consequently, there may be a risk of infecting salmonids with EN virus by holding herring at a site where salmonids are cultured. Herring may pose another risk to salmonids, and vice versa, because our results showed that herring can be infected with and carry the kidney disease bacterium, Renibacterium salmoninarum, for extended periods.

Prior to spawning in the impoundments, only 3 bacterial isolations were obtained from herring in pen P5 and none from herring in pen P1 Most bacteria were isolated from the herring after spawning had been completed in early May, possibly because of a decrease in the ability of the fish to resist pathogens and opportunistic organisms after the stress of spawning. 
The cause of the negative oxidase reaction of one of the atypical Aeromonas salmonicida isolates is perplexing. However, the oxidase reactions of the other 3 atypical A. salmonicida isolates were weakly positive and difficulty in interpreting the test may have resulted in this one test being judged negative. The negative-toweak oxidase reactions of the isolates may have resulted from poor contact with the aqueous test reagent due to the hydrophobicity of these strongly autoagglutinating organisms. Also, the negative indole test may have been a result of very poor growth of the isolates in the tryptone test medium.

Given their pathogenicity and widespread distribution, it is surprising that no Vibrio spp. were among the pathogenic isolates. However, because we did not select moribund herring there might have been a bias against isolating active pathogens of this genus, and possibly others. It should be noted that vibriosis is a threatening disease of salmonids in coastal British Columbia and has also occasionally been associated with mortalities of impounded herring (D. Kieser pers. comm.).

It has been repeatedly demonstrated that teleost fish produce an antibody response to bacterial vaccination. The subject has frequently been reviewed (Ridgeway et al. 1966, Klontz \& Anderson 1970, Snieszko 1970 , Anderson 1974, Corbel 1975). The almost total lack of response of herring to Vibrio anguillarum antigens as measured by agglutinins is surprising, especially because this vaccine stimulated high titres in chinook salmon. Environmental conditions, particularly temperature (Corbel 1975), are important in determining the immune response of fish. Although the chinook salmon were held at somewhat higher temperatures than the herring, it is doubtful that temperature alone could explain the lack of agglutinin response of juvenile herring. Perhaps herring respond more slowly or in a different way to vaccines than do salmonids. Of course, the lack of plasma agglutinin response does not necessarily imply lack of immunity of the vaccinated herring (Evelyn 1984).

Regular sampling of impounded herring resulted in the identification or isolation of some pathogens, the most notable of which were ENV and atypical Aeromonas salmonicida. Both pathogens pose a threat to salmonids and possibly to other fishes (Evelyn 1971), and it would be interesting to know if these atypical $A$. salmonicida are capable of causing disease by natural challenge, particularly in sea-pen reared salmonids. As yet, we are not aware of any losses of salmonids in sea pens in British Columbia associated with these atypical A. salmonicida. Throughout the holding period losses were low in both pens (Hay et al. 1988) and no overt epizootic occurred at either loading density. However, there is obviously a potential for high losses due to infectious disease in roe herring impoundments.
Finally, results of inoculating herring with Renibacterium salmoninarum suggest that herring might be susceptible to infections of this bacterium and/or that they could harbour $R$. salmoninarum for extended periods.

Acknowledgements. Measurements of temperature and salinity and data on mortalities were kindly provided by $H$. Kreiberg and B. Damon. We thank D. Falls and I. Keith for able assistance, and $\mathrm{Dr} T$ Trust for testing our atypical Aeromonas salmonicida with his monoclonal antibodies. We also thank Dr J. R. Brett and A. Solmie for their willing cooperation. We are very grateful to Dr L. Margolis for his helpful criticisms of the manuscript.

\section{LITERATURE CITED}

Anderson, D. P. (1974). Immunology. In: Snieszko, S. F., Axelrod, H. R. (eds.) Diseases of fishes. T F. H. Publications, Neptune City, NJ, p. 1-239

Antipa, R. (1976). Field testing of injected Vibrio anguillarum bacterins in pen-reared Pacific salmon. J. Fish. Res. Bd Can. 33: 1291-1296

Arthur, J. R., Arai, H. P. (1980). Studies on the parasites of Pacific herring (Clupea harengus pallasi Valenciennes) survey results. Can. J. Zool. 58: 64-70

Brett, J. R., Solmie, A. (1982). Roe herring impoundment research-report of the 1980/1981 studies. Can. Tech. Rep. Fish. Aquat. Sci. 1061: 1-51

Bullock, G. L., Stuckey, H. M. (1975). Fluorescent antibody identification and detection of the Corynebacterium causing kidney disease of salmonids. J. Fish. Res. Bd Can. 32: $2224-2227$

Chen, P. K., Bullock, G. L., Stuckey, H. M., Bullock, A. C. (1974). Serological diagnosis of corynebacterial kidney disease of salmonids. J. Fish. Res. Bd Can. 31: 1939-1940

Corbel, M. J. (1975). The immune response in fish: a review. J Fish. Biol. 7: 539-563

Cornick, J. W., Morrison, C. M., Zwicker, B., Shum, G. (1984) Atypical Aeromonas salmonicida infection in Atlantic cod, Gadus morhua L. J. Fish Dis. 7: 495-499

Dalsgaard, J., Paulsen, H. (1986). Atypical Aeromonas salmonicida isolated from diseased sand-eels, Ammodytes lancea (Currier) and Hyperoplus lanceolatus (Lesauvege) J. Fish Dis. 9: 361-364

Department of Fisheries and Oceans (1984). Fish health protection regulations: manual of compliance, Fish. Mar. Serv. Misc. spec. Publ. 31 (Revised): 1-43

Evelyn, T P. T. (1971). An aberrant strain of the bacterial fish pathogen Aeromonas salmonicida isolated from a marine host, the sablefish (Anoplopoma fimbria) and two species of Pacific salmon. J. Fish. Res. Bd Can. 28: 1629-1634

Evelyn, T P. T. (1977). An improved growth medium for the kidney disease bacterium and some notes on using the medium. Bull. Off. Int. Epiz. 87 (5-6): 511-513

Evelyn, T. P. T. (1984). Immunization against pathogenic vibriosis. In: de Kinkelin, P. (ed.). Symposium on fish vaccination. Office International des Épizooties, Paris, p. 121-150

Evelyn, T P. T., Traxler, G. S. (1978). Viral erythrocytic necrosis: natural occurrence in Pacific salmon and experimental transmission. J. Fish. Res. Bd Can. 35: 903-907

Hay, D. E., Brett, J. R., Bilinsiki, E., Smith, D. T., Donaldson, E. Hunter, G. A., Solmie, A. V. (1988). Experimental impoundments of prespawning Pacific herring (Clupea 
harengus pallasi): effects of feeding and density on maturation, growth, and proximate analysis Can. J. Fish. Aquat. Sci. 45: 388-398

Hugh, R., Liefson, E. (1953). The taxonomic significance of fermentative versus oxidative metabolism of carbohydrates by various Gram negative bacteria. J. Bacteriol. 66: $24-26$

Klontz, G. W., Anderson, D. P. (1970). Oral immunization of salmonids: a review. In: A symposium on diseases of fishes and shellfishes. 526 p. Spec. Publ. No. 5. American Fisheries Society, Washington, D. C., p. 16-21

Kreiberg, H., Brett, J. R., Solmie, A. (1982). Roe herring impoundment research-report on the 1981/1982 studies. Can. Tech. Rep. Fish. Aquat. Sci. 1149: 1-45

MacMillan, J. R., Mulcahy, D. (1979). Artificial transmission to and susceptibility of Puget Sound fish to viral erythrocytic necrosis. J. Fish. Res. Bd Can. 36: 1097-1101

Manual of Microbiological Methods (1957). Society of American Dacier iulogisis, MicGraw-IHill Book Co. Inc., New York

Meyers, T. R., Hauck, A. K., Blankenbeckler, W. D., Minicucci, $T$ (1986). First report of viral erythrocytic necrosis in Alaska, USA, associated with epizootic mortality in Pacific herring, Clupea harengus pallasi (Valenciennes). J. Fish Dis. 9: 479-491
Miles, A. A., Misra, S. S. (1938). The estimation of the bactericidal power of the blood. J. Hyg. 38: 732-749

Ossiander, F. J., Wedemyer, G. (1973). Computer program for sample sizes required to determine disedse incidence in fish populations. J. Fish. Res. Bd Can. 31. 1259-1261

Paterson, W. D., Dovey, D., Desautels, D. (1980). Isolation and identification of an atypical Aeromonas salmonicida strain causing epizootic losses among Atlantic salmon (Salmo salar) reared in a Nova Scotia hatchery. Can. J. Fish Aquat. Sci. 37: 2236-2241

Ridgeway, G. J., Hodgins, H. O., Klontz, G. W. (1966). The immune response in teleosts. In: Smith, R. T., Miescher, R. A., Good, R. A. (eds.) Phylogeny of immunity. University of Florida Press, Gainsville, p. 199-207

Snieszko, S. F. (1970). Immunization of fishes: a review. J. Wildl. Dis. 6: $24-30$

Taylor, F. H. C. (1985). Introduction to the international symposium on the biological characteristics of herring and their implication for management. Can. J. Fish. Aquat, Sci. 42 (Suppl. 1): 2

Trumble, R. J., Humphreys, R. D. (1985). Management of Pacific herring (Clupea harengus pallasi) in the easterm Pacific Ocean. Can. J. Fish. Aquat. Sci. 42 (Suppl. 1): 230-244

Responsible Subject Editor: Dr T. Evelyn; accepted for printing on July 22, 1988 